\title{
Applying Technology in Teaching English: Padlet, Animoto, and Sway
}

\author{
Sri Lestari \\ Universitas PGRI Madiun \\ Madiun, Indonesia \\ lestarisri@unipma.ac.id
}

\author{
Tri Wahyuni Chasanatun \\ Universitas PGRI Madiun \\ Madiun, Indonesia \\ uniechasa@gmail.com
}

\begin{abstract}
The purpose of this research is to know how the process of English learning by applying padlet, animoto, and sway application. The subjects of this study are second semester of Primary Education Department students who take English subject, and the schedule of this research began from November 2017 to June 2018. This research is a descriptive qualitative research, and the methods in collecting data used: survey, namely questionnaires, interviews, and observation. The result of this research were; first, the students are motivated joining English class. Second, students' speaking ability improve from language level ability basic User A1 to basic user A2 based on The Common European Framework of Reference for Languages (CEFR) assessment.
\end{abstract}

Keywords-ICT; padlet; animoto; sway; CEFR; speaking skill.

\section{INTRODUCTION}

Recent years, the use of Information and Communication Technology (ICT) based in education is common. Many educational practitioners use ICT in their classroom. ICTs have revolutionized the way people work today and are now transforming education systems. This ICT can help the educators in delivering their material, support their teaching learning process, and give the students task through online media, so that the students and teacher (lecturer) can be easy in conducting the teaching learning process. Schools in the Western World invested a lot for ICT infrastructures over the last 20 years, and students use computers more often and for a much larger range of applications[1]. Several studies reveal that students using ICT facilities mostly show higher learning gains than those who do not use. M. Munienge [2] states that the teachers/educators can improve teaching and learning strategies and also promote deep learning and change the learning environment into learner-centered environment by using ICT in classroom. In addition, S. Ghavifekr and W.A.W. Rosdy [3] argue that teacher who is well-equipped preparation with ICT tools and facilities could get the best result in their teaching and learning process because well-equipped preparation is one of the main factors in success of technologybased teaching and learning. In order to make the teaching learning process better, the lecturer try to use ICT Application in the classroom. The ICT Application that will be used are Padlet, Animoto, and Sway.

Padlet allows students to communicate with their classmates, as well as their teacher, in regards to class content
[4]. Padlet helps the lecturer to give the task for the students, give comment, and also the whole class can see the result of each college students' work. Students use computers more often and for a much larger range of applications [8]. Several studies reveal that students using ICT facilities mostly show higher learning gains than those who do not use. In order to make the teaching learning process better, the lecturer try to use ICT Application in the classroom. The ICT Application that will be used is Padlet and Sway. Padlet allows students to communicate with their classmates, as well as their teacher, in regards to class content [4]. Padlet helps the lecturer to give the task for the students, give comment, and also the whole class can see the result of each college student's work.

Padlet is an easy tool for English teaching learning. According to Fuchs [5], Padlet can be used for a variety of classroom purposes. It helps the teacher to have an extra guide for his/her students in order to make them easy to learn English. In other hand padlet also can be a media for the students to share their idea about what they have known related to the material that the teacher gives. They can do the task trough padlet, give comment, and make a revise for their task. It is supported by Fiester and Green [4] that Padlet allows students to communicate with their classmates, as well as their teacher, in regards to class content. Then, Sway is one of Microsoft application. Sway can help users in create interactive report, presentation, and story [6]. Furthermore, Animoto is one of simple media for presentation or slideshow based on web. The users just choose and put photos then describe it. A student can have a complete, fully animated, and quite professional-looking presentation ready for viewing in as little as fifteen minutes, and Animoto broaden as students and teachers are able to take advantage of this and many other webbased instructional tools. Furthermore Creating an Animoto video is as simple as uploading photos, choosing music, and letting it go. Animoto does all the heavy lifting, providing students with a stunning video in only a matter of minutes

The focus of subject in this research is English. English is the subject that must be learned by the college student of primary teaching education program in 2nd Semester. The material is about the Basic English. For non-English department, English is not the easy subject. If they have no interest in English at all, English can be a difficult subject for them. To reach the learning goals for this subject, that is "Students are able to identify, recognize and construct the 
competence of language, linguistic, socio-culture, strategy and attitude accurately, fluently and acceptable using English in accordance with the rules of English teaching at the college level" the lecturer should find any idea about how the way to make the English class more interesting and the college students can easy to learn. The use of ICT especially padlet, animoto, and sway are proposed. This application is part of the ICT application in which the lecturer can use it in or outside the class.

One of skill that must be learnt by students is speaking. In this research, students speaking skill will be evaluated by using The Common European Framework of Reference for Languages (CEFR) assessment. The CEFR is a framework, published by the Council of Europe in 2001, which describes language learners' ability in terms of speaking, reading, listening, and writing as six reference level. The six levels are named as follows: Basic user (A1 and A2), independent user (B1 and B2), and proficient user (CI and C2).

In this article the writer will discuss about how the process of English teaching learning by using padlet, animoto, and sway application and to know whether there is an increase or not in students' productive skills by using those application. The goal or aim of using CEFR in evaluating students' competency is to measure progress at each level of language learning [9].

\section{METHOD}

This study is a type of descriptive qualitative research. The method of collecting data are: survey which includes questionnaires, interviews, and observation. The content of questionnaires and interview are related to students' response in using padlet, animoto, and sway application as media in learning. While, in observation phase, researcher observes the English teaching and learning in class. There are 30 respondents.

\section{RESULT AND DISCUSSION}

English learning activities for students of primary teaching education program began with the delivery of learning agreements. The total of meetings in this study was 16 meetings including mid-test and final test. The material presented in this semester is Part of speech, tenses (Simple Present Tense, Present Continuous Tense, and Simple Past Tense), Reading, and also academic presentation skills. In this activity, lecturers used padlet, animoto, and sway application on student learning activity of primary teaching education program in 2nd Semester.

This is blended learning, whether the teaching learning process happened in class and online. In the classroom, students got the materials from lecturer and discussed with friends. While to improve students' ability, lecturer used the three application as a students' project in writing and speaking.

The padlet application was first used in the classroom at the second meeting, on the subject of Introducing Ourselves. In this activity, students are asked to write their introductions in English. These are the stages: First, The lecturer delivered the learning materials, simple present tense and specific conditions in using this tenses in daily life. Second, lecturer explained about padlet application and how to create and use it. Third, Students are given the task via padlet as students' project (writing) at home by the lecturer to describe thing (food, place, and people). Fourth, Lecturer checked students' work with the theme of "introduction in English" that has been collected in the links that already exist [10].

Fifth, Both lecturer and students evaluated students' project. Sixth, Lecturer checked the results of students' writing through a link that has been in student share. The result of their writing, there were still some students who are still less appropriate in using tenses and punctuation. In this case, the lecturer discussed the results of the students' work through the written "padlet" that has been printed by the lecturer. So, the results of writing that has been in print then given a note by the lecturer.

Furthermore, at the meeting of 5, 6, and 7 lecturers re-use the application of padlet with the theme of other tenses. To know the ability of each student in their understanding of simple present tense and simple past tense materials, lecturers used padlet application to assign tasks to students to write "daily activities" and also "past experience" students. In this learning, students recorded their voice related to topic and posted it. By applying padlet, students did not only post their writing, but they recorded their voice, uploaded their video, and posted pictures. In the following meeting, lecturer also used animoto as students' project in speaking. Students created their animoto and present in front of class. The topic which students presented was about branding and brand's name. Students chose of a brand, then collected the picture about it, and finally, they made animoto. At last, they presented about that brand.

The Sway app is used at the 10th to 14th meeting. This application is used by lecturers as media for students in presenting a topic. After lecturer explained about "academic presentation skill", students were asked to choose a topic to be presented using sway. The lecturer explained what sway is and how to make a presentation using sway. In the following meeting, the lecturer checked the students' work using the links they have shared. The problem with this activity is that the student is good enough to write in each slide of sway but for the speaking activities in the class, students still have problem in present it well. Thus, in next meeting, teacher asked students to make sway again and present it in front of class.

Using padlet, animoto, and sway made students are more interested in accomplishing their project in English. It was first time for them to know and use those application, so students feel interested and motivated in joining English class. Besides improving students motivation, using those application also as good alternative to give chance students in practicing their language. Below is students' ability in speaking skill after utilizing three applications. 
TABLE I. STUDENTS SPEAKING ABILITY BEFORE AND AFTER UTILIZING PADLET, ANIMOTO, AND SWAY

\begin{tabular}{|c|c|c|}
\hline $\begin{array}{l}\text { Indicator (spoken } \\
\text { language use) }\end{array}$ & Before & After \\
\hline Range & $\begin{array}{l}\text { - Most of students } \\
\text { cannot explain and } \\
\text { describe things (place, } \\
\text { people, etc) in detail. } \\
\text { - Still use simple phrase } \\
\text { related to personal } \\
\text { details and particular } \\
\text { concrete situation. } \\
\text { (Basic User A1) }\end{array}$ & $\begin{array}{l}- \\
\text { Even not too } \\
\text { fluent, students can } \\
\text { explain and describe } \\
\text { things in detail. } \\
\text { - Uses basic sentence } \\
\text { patterns with } \\
\text { memorizing phrases, } \\
\text { groups of a few words } \\
\text { and formulas in order to } \\
\text { communicate limited } \\
\text { information in simple } \\
\text { everyday situations. } \\
\text { (Basic User A2) }\end{array}$ \\
\hline Accuracy & $\begin{array}{l}\text { Shows only limited } \\
\text { control of a few simple } \\
\text { grammatical structures. } \\
\text { (Basic user A1) }\end{array}$ & $\begin{array}{l}\text { Uses some simple } \\
\text { structures correctly but } \\
\text { still systematically } \\
\text { makes basic mistakes. } \\
\text { (Basic User A2) }\end{array}$ \\
\hline Fluency & $\begin{array}{l}\text { - Only } 4 \text { students from } \\
30 \text { students who speak } \\
\text { English fluently } \\
\text { because limited of } \\
\text { vocabulary and content } \\
\text { - Still much pausing } \\
\text { to search for } \\
\text { expressions, to } \\
\text { articulate less familiar } \\
\text { words (Basic User A1) }\end{array}$ & $\begin{array}{l}\text { - Understood in very } \\
\text { short utterance, even } \\
\text { though pauses. } \\
\text { - After } \\
\text { meetings, several } \\
\text { percentage of students } \\
\text { fluency in speaking } \\
\text { improve, become 11 } \\
\text { students (Basic User } \\
\text { A2) }\end{array}$ \\
\hline Interaction & $\begin{array}{l}\text { - Can ask and answer } \\
\text { question about personal } \\
\text { details } \\
\text { - Can interact in a } \\
\text { simple way but } \\
\text { communication is } \\
\text { totally dependent on } \\
\text { repetition (Basic User } \\
\text { A1) }\end{array}$ & $\begin{array}{l}\text { - Can answer questions } \\
\text { and respond to simple } \\
\text { statement. } \\
\text { - Rarely able to } \\
\text { understand enough to } \\
\text { keep conversation } \\
\text { going of his/her own } \\
\text { accord (basic User A2) }\end{array}$ \\
\hline Coherence & $\begin{array}{l}\text { Can link words or } \\
\text { groups of words with } \\
\text { very basic linear } \\
\text { connectors like "and or } \\
\text { then" (Basic User A1) }\end{array}$ & $\begin{array}{l}\text { Can link groups of } \\
\text { words with simple } \\
\text { connectors like "and, } \\
\text { but, and become" Basic } \\
\text { User A2) }\end{array}$ \\
\hline
\end{tabular}

From those result, it can be concluded that there was improvement in students' speaking ability. Generally, students' competence was in level Basic User A2 from Basic User A1.

TABLE II. THE TOTAL OF STUDENTS' LANGUAGE LEVEL ABILITY

\begin{tabular}{|c|c|c|c|}
\hline No. & Language & Total & Of Percentage \\
\hline 1. & $\mathrm{C} 2$ & 0 & - \\
\hline 2. & $\mathrm{C} 1$ & 0 & - \\
\hline-3. & B2 & 0 & - \\
\hline 4. & B1 & 2 & $6,66 \%$ \\
\hline 5. & A2 & 12 & $40 \%$ \\
\hline 6. & A1 & 16 & $53,3 \%$ \\
\hline & Total & 30 & $100 \%$ \\
\hline
\end{tabular}

Based on table above, it can be seen that only 2 students who get the level Independent User B1, and 12 students in level Basic User A2, and the remains are in level basic user A1. Based on the observation in this research, from previous meeting before utilize three application (technology), most of students still not confident to talk and answers the questions. They tend to keep silent and difficult to interact or communicate each other. After lecturer introduced the padlet, animoto, and sway in teaching, students looked interested to accomplish the project both in speaking and writing. Beside evaluate students' competence, researcher also check students' response after applying those application. Here the result of questionnaires:

TABLE III. QUESTIONNAIRE RESULTS

\begin{tabular}{|c|c|c|c|c|}
\hline \multirow[b]{2}{*}{ Items } & \multicolumn{4}{|c|}{ The Percentage of Respondents (\%) } \\
\hline & $\begin{array}{l}\text { Strongly } \\
\text { Disagree }\end{array}$ & Disagree & Agree & $\begin{array}{c}\text { Strongly } \\
\text { Agree }\end{array}$ \\
\hline $\begin{array}{l}\text { Using application } \\
\text { Animoto, padlet, } \\
\text { and sway allows } \\
\text { students' to be more } \\
\text { creative } \\
\text { imaginativer and }\end{array}$ & & & 13.33 & 86.67 \\
\hline $\begin{array}{l}\text { The use of animoto, } \\
\text { padlet, and sway } \\
\text { helps students to } \\
\text { find } \\
\text { knowledge related } \\
\text { information } \\
\text { learning }\end{array}$ & & & 63.33 & 36.67 \\
\hline $\begin{array}{l}\text { The use of animoto, } \\
\text { padlet and sway } \\
\text { encourages students } \\
\text { to communicate } \\
\text { more with their } \\
\text { classmates. }\end{array}$ & & 3.33 & 86.67 & 10 \\
\hline $\begin{array}{l}\text { The use of animoto, } \\
\text { padlet, and sway, } \\
\text { increases students' } \\
\text { confidence to } \\
\text { participate actively } \\
\text { in the class. }\end{array}$ & & & 73.33 & 26.67 \\
\hline $\begin{array}{l}\text { I think students } \\
\text { learn more } \\
\text { effectively with the } \\
\text { use of animoto, } \\
\text { padlet, and sway. }\end{array}$ & & & 90 & 10 \\
\hline $\begin{array}{l}\text { I think the use of } \\
\text { animoto, padlet, and } \\
\text { sway helps to } \\
\text { improve students' } \\
\text { ability specifically } \\
\text { in speaking and } \\
\text { writing }\end{array}$ & & 6.67 & 40 & 53.33 \\
\hline $\begin{array}{l}\text { The students' are } \\
\text { more behaved and } \\
\text { under control with } \\
\text { the use of animoto, } \\
\text { padlet, and sway. }\end{array}$ & & & 83.33 & 16.67 \\
\hline $\begin{array}{l}\text { The use of animoto, } \\
\text { padlet, and sway } \\
\text { enables students' to }\end{array}$ & & & 13.33 & 86.67 \\
\hline
\end{tabular}




\begin{tabular}{|l|l|l|l|l|}
\hline $\begin{array}{l}\text { express their ideas } \\
\text { and thoughts better. }\end{array}$ & & & & \\
\hline $\begin{array}{l}\text { The use of animoto, } \\
\text { padlet, and sway } \\
\text { promotes active and } \\
\text { engaging lesson for } \\
\text { students best } \\
\text { learning experience. }\end{array}$ & & & 53.33 & 46.67 \\
\hline
\end{tabular}

From table above, it can be concluded that 30 students have positive response in using padlet, animoto, and sway in learning English. Those application are as media to help them to be more creative in accomplishing their project. There are some strengthen and weaknesses in using them, the strengths are: easy to apply, interactive, and more communicative. While the weaknesses are: depends on online data.

\section{CONCLUSION}

The use of padlet, animoto, and sway application can motivate students in learning English. It is proven by students' response in answering the questionnaires. Learning in classroom just for sharing and discussing the material, while using the application as for practicing in both speaking and writing. This research focus on evaluating students' ability in speaking. Based on reviewing students' performance in classroom and checking students' recording in padlet, it can be concluded that students ability improve from language level ability basic user A1 to basic user A2. Beside, these application can be used not only for teaching English but for another subjects because animoto and sway can be an alternative in presenting a topic. While, padlet can be used for posting assignment and sharing related to the assignment with friends in that wall. In conclusion, it is recommended that further studies conducting on this topic, using larger data collections, quantitative and qualitative survey instruments and other software applications.

\section{REFERENCES}

[1] L. Cynthia K. "The Effects of Using Padlet on the Academic Performance and Engagement of students in a fifth grade basic skills Mathematics classroom”. Rowan Digital Works, Rowan University: New Jersey, United States, 2017.

[2] M. Munienge, "Integration of ICT in Education: Key Challenges, Scholarly Journal of Mathematics and Computer Science", International Journal of Emerging Technology and Advanced Engineering, vol. 3, pp. 515-520, 2015.

[3] S. Ghavifekr and W.A.W. Rosdy, "Teaching and learning with technology: Effectiveness of ICT integration in schools", International Journal of Research in Education and Science (IJRES), 1(2), pp. 175191.

[4] H. Fiester and T. Green, "Students use of backchanneks. TechTrends", pp. 404-408, 2016.

[5] F. Beth, "The Writing is on the Wall: Using Padlet for Whole-Class Engagement", Library Faculty and Staff Publication, USA, 2014

[6] Sway (2018, February). Available: hhtp://sway.com
[7] C. Abdullah and Z. Marlowe, "Technology in ELT: English Teachers Investigate Animoto and Fotobabble", interntional Journal of Higher Education, vol. 4, 2015.

[8] Animoto. (2018, February). Available: http://animoto.com/

[9] B. Dylan, "Globally Recognized Proficiency Scales: The goals and Uses of CEFR, "British Council, Indonesia, March 2018.

[10] Padlet. (2018, February). Available: http://www.padlet.com. 